\title{
Correction: Oxidative DNA damage correlates with cell immortalization and mir-92 expression in hepatocellular carcinoma
}

\author{
Romilda Cardin ${ }^{1}$, Marika Piciocchi ${ }^{1}$, Alessandro Sinigaglia ${ }^{2,4}$, Enrico Lavezzo ${ }^{2}$, Marina Bortolami ${ }^{1}$, \\ Andromachi Kotsafti ${ }^{1}$, Umberto Cillo ${ }^{3}$, Giacomo Zanus $^{3}$, Claudia Mescoli ${ }^{5}$, Massimo Rugge ${ }^{5}$ and Fabio Farinati ${ }^{1,6^{*}}$
}

\section{Correction}

After publication of this work [1], we noted that all the names and surnames of the authors have been swapped. Now the order of names and surnames of all authors has been corrected as follows: "Cardin R, Piciocchi M, Sinigaglia A, Lavezzo E, Bortolami M, Kotsafti A, Cillo U, Zanus G, Mescoli C, Rugge M, Farinati F” (Surname Name).

\begin{abstract}
Author details
'Department of Surgical and Gastroenterological Sciences, Section of Gastroenterology, Padua University, Padua, Italy. ${ }^{2}$ Department of Histology, Microbiology and Medical Biotechnologies, Padua University, Padua, Italy. ${ }^{3}$ Department of Surgical and Gastroenterological Sciences, Hepatobiliary Surgery and Liver Transplant Unit, Padua University, Padua, Italy. ${ }^{4}$ IRCCS Venetian Oncology Institute (IOV), Padua, Italy. ${ }^{5}$ Department of Medical Diagnostic Sciences \& Special Therapies, Pathology Unit, Padua University, Padua, Italy. ${ }^{6}$ Dipartimento di Scienze Chirurgiche e Gastroenterologiche, Policlinico Universitario, Via Giustiniani 2, Padova 35128, Italy.
\end{abstract}

Received: 14 March 2014 Accepted: 19 March 2014

Published: 23 April 2014

\section{Reference}

1. Romilda C, Marika P, Alessandro S, Enrico L, Marina B, Andromachi K, Umberto C, Giacomo Z, Claudia M, Massimo R, Fabio F: Oxidative DNA damage correlates with cell immortalization and mir-92 expression in hepatocellular carcinoma. BMC Cancer 2012, 12:177. 10.1186/1471-2407-12177.

\section{doi:10.1186/1471-2407-14-284}

Cite this article as: Cardin et al:: Correction: Oxidative DNA damage correlates with cell immortalization and mir-92 expression in hepatocellular carcinoma. BMC Cancer 2014 14:284.

\footnotetext{
*Correspondence: fabio.farinati@unipd.it

${ }^{1}$ Department of Surgical and Gastroenterological Sciences, Section of Gastroenterology, Padua University, Padua, Italy

${ }^{6}$ Dipartimento di Scienze Chirurgiche e Gastroenterologiche, Policlinico Universitario, Via Giustiniani 2, Padova 35128, Italy
}

Submit your next manuscript to BioMed Central and take full advantage of:

- Convenient online submission

- Thorough peer review

- No space constraints or color figure charges

- Immediate publication on acceptance

- Inclusion in PubMed, CAS, Scopus and Google Scholar

- Research which is freely available for redistribution

\section{() Biomed Central}

\section{Biomed Central}

(c) 2014 Cardin et al.; licensee BioMed Central Ltd. This is an Open Access article distributed under the terms of the Creative Commons Attribution License (http://creativecommons.org/licenses/by/4.0), which permits unrestricted use, distribution, and reproduction in any medium, provided the original work is properly credited. The Creative Commons Public Domain Dedication waiver (http://creativecommons.org/publicdomain/zero/1.0/) applies to the data made available in this article, unless otherwise stated. 